IRA-International Journal of Education \& Multidisciplinary Studies ISSN 2455-2526; Vol.07, Issue 03 (2017) Pg. no. 190-199

Institute of Research Advances http://research-advances.org/index.php/IJEMS

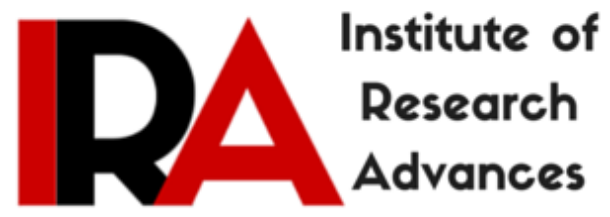

\title{
Family Factors and Academic Achievement: A Comparative Study of Residential School Children and Rural Government School Children
}

\author{
S. Ashwini Kumari ${ }^{1}$, Saritha Devi' ${ }^{2}$ K. Mayuri $^{3}$ \\ ${ }^{1 \& 2}$ M.Sc. Students, Department of Human Development and Family Studies, College of \\ Home Science, ANGR Agricultural University, Hyderabad. \\ ${ }^{3}$ Professor and Head of the Department, Department of Human Development and Family \\ Studies, College of Home Science, ANGR Agricultural University, Hyderabad.
}

Type of Review: Peer Reviewed.

DOI: http://dx.doi.org/10.21013/jems.v7.n3.p3

\section{How to cite this paper:}

Kumari, S., Devi, S., \& Mayuri, K. (2017). Family Factors and Academic Achievement: A Comparative Study of Residential School Children and Rural Government School Children. IRA International Journal of Education and Multidisciplinary Studies (ISSN 2455-2526), 7(3), 190199. doi:http://dx.doi.org/10.21013/jems.v7.n3.p3

(C) Institute of Research Advances.

\section{(c) EY-NO}

This work is licensed under a Creative Commons Attribution-Non Commercial 4.0 International License subject to proper citation to the publication source of the work.

Disclaimer: The scholarly papers as reviewed and published by the Institute of Research Advances (IRA) are the views and opinions of their respective authors and are not the views or opinions of the IRA. The IRA disclaims of any harm or loss caused due to the published content to any party. 


\begin{abstract}
The study compares the effects of family factors contributing to the High Academic Achievement of Private Residential School Children and Rural Government School Children. Children studying in selected private residential schools and rural government schools in IX and X classes with highest ranks (first 3-4 ranks) in the previous year were selected. Total sample comprised 240 children, 120 from each setting, 60 from IX class and 60 from X class. An Interview schedule was developed by the investigator for the children to know their perceptions about family contributing factors. The study concluded that children of Private Residential Schools and Rural Government Schools were average and similar in their perceptions regarding parental contributions for their Academic Achievement. High Parental Aspirations Expectations helped in high achievement in both groups but comparatively high in Private Residential School children. Whereas contribution of Siblings Relationship and Assistance of others was high in Rural Government School children and average in Private Residential School children. Coming to the gender and age variations in family contributing factors, there was significantly high parental contributions for Academic Achievement of boys than girls in private Residential schools and higher age group children of Rural Government schools have significantly more parental contribution for their Academic Achievement than lower age group children. Achievement in English was highly positively correlated with family's Economic status in Private Residential schools. There was significant positive correlation between achievement in mathematics and parental contribution, achievement in science and Parental Aspirations in Rural Government School children.
\end{abstract}

Key words: Academic Achievement, Family factors, Rural Government school children, Private residential school children

\title{
INTRODUCTION
}

Family is the primary socializing agent and decisive factor in child's educational and economic success. Family back ground is strongly correlated with academic performance of the individual. The internal and external interactions of the family will influence the academic success of the individual. The association between home life and school performance is vital aspects for research and exploration. So it is important to study the home and family environment and its correlation with educational attainment in rural and urban settings.

\section{General objective}

To compare the family factors contributing to the high Academic Achievement of private residential school children and rural government school children.

\section{Specific objectives}

1. To compare the family factors contributing to the Academic Achievement of IX and X class private residential school children and rural government school children.

2. To compare the gender and age differences in family factors of private residential school children and rural government school children.

\section{REVIEW OF LITERATURE}

Previous studies on family factors and Academic Achievement are related to Parental Education and Occupation, Socio Economic Status, Home environment, Parental behavior.

Many studies reported positive relationship of parental education and occupation with child's Academic Achievement (Jagannadham,1985; Lohani and Mohite,1990; De Tinku and Chandra, 1994: Audinarayana, 1996; cherian, 1996; Vijaya laxmi, 1997 \& Suneetha, 1997; Suneetha and Mayuri, 1999). Mother's occupation showed significant relationship with achievement of girls (Trivedi 1988). 
Studies of Budhdev (1999) highlight achievement among the children of working mothers with no significant difference in Academic Achievement of girls and boys. Budhdev's (1995) earlier study concluded insignificant effect of parental education and occupation on child's Academic Achievement. Adolescents of non-working mothers score higher in academic achievement and creativity (Bala and Nanda, 2007).

Both parents' level of education and reading material available in the home were related to children's' academic achievement (Zahyah,2008). Among the higher parental education group, parent's academic involvement was related to fewer behavioral problems, which were related to achievement and then aspirations (Hill et al.,2004).

Family's background the most important and the weightiest factor in determining the academic performance attained by the student (Diaz, 2003).The family environment factors when combined together play a significant role in social, emotional and educational adjustment of the adolescent girls in rural areas (Deepshikha 2009).

Research done in the United States shows that parental involvement in children's education positively effects academic achievement (Muller 1993; Ho Sui-Chu and Willms 1996; Epstein 2001).

Studies showed significant positive relationship between family's economic status and Academic Achievement (Jagannadhan, 1996; Mohanty \& Das,1997; Suneetha, 1997; Agarwal and sandhya, 1998; Suneetha and Mayuri 1999; Taj 1999, Lan 2005). In contrast, a study of Budhdev (1995) revealed insignificant effect of parental income on Academic Achievement.

Studies on home environment proved better the home environment better in the Academic Achievement (Lohani \& Mohite, 1990; Thakur, 2001). Supportive warm favorable home environment is associated with High achievement (Ladd \& Prince, 1986; Bandura, Barbaranelli, Caprola \& Postotelli, 1996; Khare, 1996, Lakshmi and Arora, 2006). In a study of Verma and Gupta (1996) home environment and intelligence were significantly correlated only for boys.

Boys and girls differed in perception of the home and environment (Mohanraj and Latha, 2005). Good quality of home environment had significant positive correlation with high level of scholastic achievement in boys than among girls, also, the quality of home environment gets deteriorated, the level of scholastic achievement also comparatively declines in boys (Meena, 2008).

Substantial proportion of adolescent males who perceived parent adolescent interactions as a positive effect were more likely to have high achievement than those who did not perceive parent-adolescent interaction as positive (Shearin, 2002; Thomas, 2002).

Home environments and educational activities are important factors of student's academic achievement. Students from families supportive of learning are likely to have higher achievement scores and home environments and educational activities account for a large part of the difference in student achievement between Asian American and other minority students (Peng and Wright, 1994).

Factors of poor home environment like alcoholism among fathers (Kannappan, 1989), divorce among parents (Cherian \& Cherian, 1995) tends to increase academic failure among children. Family distress, conflict and environment might significantly have impacts on school performance and school related behavioural problems (Golbert 2004). 
Studies on parental behavior showed that Academic Achievement is influenced by the quality of adolescent's relationship with his parents and other family members (Dorn Busch et.al, 1987; Stevenson \& Baker, 1987; Taj, 1999). Parent involvement fuels academic performance (Grolnick \& Slowiaczek, 1994). Achievement is higher in children who perceive their parents as loving and demanding (Suman \& Umapathy, 1992).

Parents of low achievers were found to be less accepting, less encouraging and less democratic (Kang \& Sibia, 1997). Achievement is better where there is consistent discipline, non enforcement and lack of discipline (Ahmed and Saluja 1988). Academic Achievement is influenced by family's general levels of academic aspirations (Dorn Busch et. al 1987; Stevenson and Baker, 1987).

Parenting style was found to be significantly related to adolescent's academic achievement (Pittman and Lansdale 2001). Parents have significantly low aspiration, lesser need for achievement and lesser expectation in education for girl's education than boys (Bhati 2008).

There is a positive and significant relationship between parental involvement and academic achievement. There was a significant difference in the achievement scores of boys and girls of high parental involvement group. There was no significant difference in the achievement scores of boys and girls of low parental involvement group. There was significant difference between high achievers and low achievers with respect to parental involvement. There was significant difference between boys and girls in their academic achievement (Vamadevappa ,2005).

\section{MATERIALS AND METHODS \\ Sampling procedure}

\section{Selection of schools}

Popular Private Residential Schools were selected from daily news paper advertisements from different localities of Hyderabad City. Rural government schools which had got more than 60 percent results in last three consecutive years were selected from the office of commissionerate of examination. A total of 17 schools was listed and selected.

\section{Selection of children}

Children studying in selected private residential schools and rural government schools in IX and X classes with highest ranks (first 3-4 ranks) in the previous year were selected. Total sample comprised120 children, 60 from IX class and 60 from X class.

\section{Tools and Techniques}

Interviews scheduled for the children to know their perceptions about family contributing factors.

\section{Statistical procedure used for the data analysis}

Percentages, Arithmetic Mean, Standard Deviation, Two Sample Z Test, correlation were used for the analysis of the data.

\section{RESULTS}

\section{TABLE-1}

COMPARISON OF FREQUENCY DISTRIBUTION OF CHILDREN'S PERCEPTIONS ABOUT FAMILY CONTRIBUTING FACTORS OF PRIVATE RESIDENTIAL SCHOOL CHILDREN AND RURAL GOVERNMENT SCHOOL CHILDREN ( $\mathrm{N}=120)$ 


\begin{tabular}{|c|c|c|c|c|c|c|c|c|}
\hline \multirow[t]{2}{*}{ Dimension } & \multirow[t]{2}{*}{ HPS } & & \multicolumn{6}{|c|}{ Categories of scores obtained } \\
\hline & & & $0-5$ & $6-10$ & $11-15$ & $16-20$ & $21-25$ & $26-30$ \\
\hline \multirow[t]{2}{*}{$\begin{array}{l}\text { Parental } \\
\text { contribution }\end{array}$} & 45 & Private residential & - & $\begin{array}{l}2 \\
(1.67)\end{array}$ & $\begin{array}{l}26 \\
(21.67)\end{array}$ & $\begin{array}{l}37 \\
(30.73)\end{array}$ & $\begin{array}{l}55 \\
(46.03)\end{array}$ & \\
\hline & & Rural Government & - & $\begin{array}{l}6 \\
(5) \\
\end{array}$ & $\begin{array}{l}30 \\
(25) \\
\end{array}$ & $\begin{array}{l}74 \\
(61.6) \\
\end{array}$ & $\begin{array}{l}8 \\
(6.7) \\
\end{array}$ & $\begin{array}{l}2 \\
(1.7) \\
\end{array}$ \\
\hline \multirow[t]{2}{*}{$\begin{array}{l}\text { Parental } \\
\text { Aspirations }\end{array}$} & 31 & Private residential & - & - & - & $\begin{array}{l}1 \\
(0.83)\end{array}$ & $\begin{array}{l}49 \\
(40.07)\end{array}$ & $\begin{array}{l}70 \\
(59.10)\end{array}$ \\
\hline & & Rural Government & & & $\begin{array}{l}10 \\
(8.3)\end{array}$ & $\begin{array}{l}32 \\
(26.7)\end{array}$ & $\begin{array}{l}76 \\
(63.3)\end{array}$ & $\begin{array}{l}2 \\
(1.8)\end{array}$ \\
\hline \multirow{2}{*}{$\begin{array}{l}\text { Sibling } \\
\text { Relationship } \\
\text { and } \\
\text { Assistance }\end{array}$} & 15 & Private residential & $\begin{array}{l}6 \\
(5.0) \\
\end{array}$ & $\begin{array}{l}98 \\
(81.66)\end{array}$ & $\begin{array}{l}16 \\
(13.34)\end{array}$ & & & \\
\hline & & Rural Government & $\begin{array}{l}6 \\
(5)\end{array}$ & $\begin{array}{l}44 \\
(36.7)\end{array}$ & $\begin{array}{l}70 \\
(58.3)\end{array}$ & & & \\
\hline
\end{tabular}

HPS : Highest possible Score. Percentages in Parenthesis

TABLE-2

\begin{tabular}{|c|c|c|c|c|c|}
\hline \multirow{2}{*}{ Dimension } & \multirow[t]{2}{*}{ HPS } & & \multicolumn{3}{|c|}{ Categories of scores obtained } \\
\hline & & & Below Average & average & high \\
\hline \multirow{2}{*}{$\begin{array}{l}\text { Parental } \\
\text { contribution }\end{array}$} & 45 & Private residential & 23 & 77 & - \\
\hline & & Rural Government & 30 & 70 & - \\
\hline \multirow{2}{*}{$\begin{array}{l}\text { Parental } \\
\text { Aspirations }\end{array}$} & 31 & Private residential & - & $<1$ & $>99$ \\
\hline & & Rural Government & - & 35 & 65 \\
\hline \multirow{2}{*}{$\begin{array}{l}\text { Sibling } \\
\text { Relationship } \\
\text { and } \\
\text { Assistance }\end{array}$} & 15 & Private residential & 5 & 81.7 & 13.3 \\
\hline & & Rural Government & 5 & 37 & 58 \\
\hline
\end{tabular}

HPS : Highest possible Score. Percentages in Parenthesis

It is clear from the above tables that 77 percent of Private Residential School children perceived average parental Contributions towards their Academic Achievement. Whereas 70 percent of Rural Government School Children perceived average parental contributions. In both groups none of them perceived high parental contributions towards their Academic Achievement.

It can be inferred from the above results that both private Residential School Children and Rural Government School Children are similar in parental Contributions for their Academic Achievement even though Private Residential School Children were away from their parents and Rural Government School Children were staying with their parents.

Coming to the parental Aspirations and Expectations, more than 99 percent of Private Residential School Children perceived high parental Aspirations and Expectations. Perception of average parental Aspirations was very negligible as it is less than 1percent. It is obvious as because of high Aspirations and expectations, parents are putting them in residential schools. Whereas 65 percent of Rural Government School Children perceived high parental Aspirations and Expectations. 35 percent of them perceived average parental Aspirations. 
82 percent of Private Residential School Children perceived average Sibling's assistance for their Academic Achievement. Only 13percent of them felt high siblings' assistance for their Academic Achievement. Rest of them perceived below average assistance from siblings. Coming to the Rural Government School Children more than half i.e., 58 percent perceived high Sibling Assistance of others is more for Rural Government School Children than private Residential School Children as later are away from family environment and siblings.

TABLE-3

COMPARISON OF MEAN SCORES ON CHILDREN'S PERCEPTIONS ABOUT FAMILY CONTRIBUTING FACTORS OF PRIVATE RESIDENTIAL SCHOOL CHILDREN AND RURAL GOVERNMENT SCHOOL CHILDREN BY GENDER

\begin{tabular}{|c|c|c|c|c|c|c|}
\hline \multirow[t]{2}{*}{ Dimension } & & \multicolumn{2}{|l|}{ Boys } & \multicolumn{2}{|l|}{ Girls } & \multirow[t]{2}{*}{$\mathrm{Z}$-value } \\
\hline & & Mean & SD & Mean & SD & \\
\hline \multirow{2}{*}{$\begin{array}{l}\text { Parental } \\
\text { contribution }\end{array}$} & Private residential & 17.56 & 3.9595 & 16.52 & 2.77 & $2.0655^{*}$ \\
\hline & Rural Government & 16.7222 & 3.3603 & 16.6908 & 3.5363 & 0.0466 \\
\hline \multirow{2}{*}{$\begin{array}{l}\text { Parental } \\
\text { Aspirations }\end{array}$} & Private residential & 24.26 & 2.7692 & 24.82 & 2.80 & 1.0410 \\
\hline & Rural Government & 20.7778 & 3.5384 & 21 & 2.6886 & 0.3373 \\
\hline \multirow{2}{*}{$\begin{array}{l}\text { Sibling } \\
\text { Relationship } \\
\text { and } \\
\text { Assistance }\end{array}$} & Private residential & 12.38 & 1.9202 & 12.20 & 2.01 & 0.4881 \\
\hline & Rural Government & 10.2222 & 2.9190 & 10.6904 & 2.2260 & 0.8690 \\
\hline \multirow{2}{*}{$\begin{array}{l}\text { Economic } \\
\text { Status }\end{array}$} & Private residential & 12825.00 & 6478.2 & 11625.00 & 6048.5 & 1.0003 \\
\hline & Rural Government & 2672.22 & 1094.3 & 3016.905 & 1404.631 & 1.6357 \\
\hline
\end{tabular}

$* \mathrm{P}<0.05 \quad$ HPS : Highest possible Score. Percentages in Parenthesis

Coming to the gender variations in Private Residential School Children and Rural Government School Children with regard to their perceptions about family contributing factors, there were no significant gender differences in children from both settings except in parental contributions for private Residential School Children. There is significant difference between boys and girls of private residential schools about their perceptions regarding the parental contributions. Boys of Private Residential School s perceived significantly high parental contributions for their Academic Achievement than girls.

\section{TABLE-4}

COMPARISON OF MEAN SCORES ON CHILDREN'S PERCEPTIONS ABOUT FAMILY CONTRIBUTING FACTORS OF PRIVATE RESIDENTIAL SCHOOL CHILDREN AND RURAL GOVERNMENT SCHOOL CHILDREN BY AGE

\begin{tabular}{|l|l|l|l|l|l|l|}
\hline Dimension & \multicolumn{3}{|l|}{ 14 YEARS } & \multicolumn{1}{l}{ 15 YEARS } & \multirow{2}{*}{ Z-value } \\
\hline & & Mean & SD & Mean & SD & \\
\hline \multirow{2}{*}{$\begin{array}{l}\text { Parental } \\
\text { contribution }\end{array}$} & Private residential & 16.13 & 3.25 & 18.30 & 3.67 & 3.4169 \\
\cline { 2 - 7 } $\begin{array}{l}\text { Parental } \\
\text { Aspirations }\end{array}$ & Rural Government & 18.2333 & 3.0992 & 15.1666 & 3.1470 & $5.3779 * *$ \\
\cline { 2 - 7 } $\begin{array}{l}\text { Sibling } \\
\text { Relationship } \\
\begin{array}{l}\text { and } \\
\text { Assistance }\end{array}\end{array}$ & Rural Government & 24.46 & 2.66 & 24.43 & 2.91 & 0.06 \\
\cline { 2 - 7 } & Private residential & 12.28 & 2.5398 & 21.1667 & 3.3251 & 0.8639 \\
\hline
\end{tabular}


IRA-International Journal of Education \& Multidisciplinary Studies

\begin{tabular}{l|l|l|l|l|l|l|}
\hline Economic & Private residential & 12133.3 & 6248.9 & 121716.6 & 6462.9 & 0.5026 \\
\cline { 2 - 7 } Status & Rural Government & 2773.33 & 1319.71 & 3116.66 & 1322.57 & 1.4233 \\
$*$ P $<0.05$ & HPS : Highest possible Score. Percentages in Parenthesis
\end{tabular}

It is clear from the above table that there is no significant age difference in children's perceptions about their family contributing factors in both groups of children, expect in parental contributions for Rural Government School Children.

Children of higher age group from Rural Government Schools perceived significantly high parental contributions than lower age group children. This may be due to parents giving more attention to higher class children. With regard to Private Residential School Children, as they are away from parental interaction, there is average parental contribution and not much difference between higher age and lower age group children.

\section{TABLE-5}

COMPARISON OF CORRELATION BETWEEN FAMILY FACTORS AND ACADEMIC ACHIEVEMENT OF PRIVATE RESIDENTIAL SCHOOL CHILDREN AND RURAL GOVERNMENT SCHOOL CHILDREN

\begin{tabular}{|l|l|l|l|l|}
\hline Dimension & & English & Mathematics & Science \\
\hline & & & & \\
\hline \multirow{2}{*}{ Parental contributions } & Private residential & 0.1274 & 0.1022 & -0.1246 \\
\cline { 2 - 5 } & Rural Government & 0.0138 & $0.2253^{*}$ & 0.1215 \\
\hline \multirow{2}{*}{ Parental Aspirations } & Private residential & -0.0156 & 0.2180 & 0.1453 \\
\cline { 2 - 5 } & Rural Government & 0.1763 & 0.867 & $0.3376^{* *}$ \\
\hline \multirow{2}{*}{$\begin{array}{l}\text { Sibling Relationship and } \\
\text { Assistance }\end{array}$} & Private residential & 0.0826 & 0.1563 & 0.1106 \\
\cline { 2 - 5 } & Rural Government & 0.1289 & 0.0742 & 0.1982 \\
\hline $\begin{array}{l}\text { Economic } \\
\text { Status }\end{array}$ & Private residential & $0.3460^{* *}$ & 0.993 & 0.0387 \\
\cline { 2 - 5 } & Rural Government & -0.0275 & 0.0742 & 0.1532 \\
\hline
\end{tabular}

$* \mathrm{P}<0.05 \quad * * \mathrm{p}<0.01$

It is evident from the above table that there is no significant correlation between family contributing factors and achievement in English except Economic status of the family of private Residential School Children. In Private Residential School Children, family's Economic status was positively correlated with achievement in English. Higher the family's income, higher the achievement in English subject.

Coming to the achievement in mathematics and science, family contributing factors does not showed significant correlation with Academic Achievement except Parental Contributions for achievement in Mathematics and Parental Aspirations for achievement in science for Rural Government School Children.

Parental contributions were significantly positively correlated with achievement in mathematics for Rural Government School Children. Higher the parental contribution, higher the achievement in Mathematics for this group. Achievement in Science was highly positively correlated with Parental Aspirations for Rural Government School Children, higher the aspirations higher the achievement in Science for Rural Government School Children.

From the above discussion it can be concluded that children of private Residential Schools and Rural Government Schools were average and similar in their perceptions regarding parental contributions for their Academic Achievement. High Parental Aspirations and Expectations helped in high achievement in both groups but comparatively high in Private Residential School children. Whereas contribution of 
Siblings Relationship and Assistance of others was high in Rural Government school Children and average in Private Residential School children.

Coming to the gender difference in family contributing factors there was significantly high parental contributions for Academic Achievement of boys than girls in Private Residential School Children. In other aspects there was no gender variation in both groups of children. Coming to the average variation, higher age group children of Rural Government School children have significantly more parental contribution for their Academic Achievement than lower age group children. Otherwise there is no significant age difference in family contributing factors for both groups of children.

Achievement in English was highly positively correlated with family's Economic Status in Private Residential Schools there was significant positive correlation between achievement of mathematics and parental contribution, achievement of Science and Parental Aspirations in Rural Government School Children.

\section{References}

1. Agarwal, S. (1998). A study on factors affecting the scholastic achievement of X class science girls of identical variables. Perspectives in Psychological Researches, 21(1\&2), 55-59.

2. Ahmad, A. \& Saluja, R.K. (1985). A study of scholastic achievement in relation to children report of parental behavior. Asian journal of Psychology \& Education, 21 (4-5), 15-20

3. Audinarayana, N. (1996).Family size and Academic Achievement of children. Journal of family welfare, 42(3), 46-50.

4. Bala, Renu and Nanda, Kaur, Paramjeet (2007). Impact of Maternal Employment on Personality Traits of Urban Adolescents. Indian Journal of Psychometry and Education, 38(2): 148-152.

5. Bandura, A.,Barbaranelli, C.,Caprara,G.V. \& Postorelli, C. (1996). Multifaceted impact of self efficacy beliefs on academic functioning. Child Development, 67,1206 - 1222.

6. Bhati, H.S. (2008). Demand constraints and exclusion of girls from educational system: an analysis of rural area parents of Noida (Western U.P.). Behavioural Scientist, 9(2): 99-106.

7. Budhdev, P.V. (1995). Academic Achievement and attitude towards science subject of secondary school students of different parental education, occupation and income. Asian Journal of Psychology \& Education, 28(3-4),12-16.

8. Budhdev, P.V. (1999). Academic Achievement among children of working and non working mothers. Indian psychological review, 52(2),69-73

9. Cherian, V.I. \& Cherian, L. (1995). Relationship between divorce, gender, SES, unhappiness and mathematics achievement of children. Journal of family welfare, 45(1),20-25.

10. Cherian, V.I. \& Cherian, L. (1995). Relationship between parental occupation and Academic Achievement of Xhosa children from polygynous and monogamous families. Journal of Family welfare, 41(2), 20-28.

11. Deepshikha (2009). Role of family environment on socio-emotional and educational adjustment of adolescent girls in rural areas of eastern U.P. Dissertation Thesis (Human Development), Department of Human Development, College of home Science, N.D. University of Agriculture and Technology, Narendra Nagar (Kumarganj), Faizabad, U.P., India.

12. Diaz, Antonia, Lozono (2003). Personal, family and academic factors affecting low achievement in secondary school. Journal of Research in Educational Psychology, 1(1): 43-66.

13. Dornbusch, S.M., Ritter,P.L., Leiderman, P.H., Robert, D.F. \& Fraleigh, M.J., (1987).The relation of parenting style to adolescent school performance. Child Development, 58, 1244-1257.

14. Epstein, Joyce L. (2001). School, Family and Community Partnerships: Preparing Educators and Improving Schools. Boulder, Co.: West view. 
15. Grolnick, W.S. \& Slowiaczek, M.L. (1994). Parents involvement in children's schooling : A multidimensional conceptualization and motivational model. Child Development, 65, 237-252

16. Hill, E. Nancy; Castellino, R. Domini; Lansford, E. Jennifer; Nowlin, Patrick; Dodge, A. Kenneth; Bates, E. John; and Pettit, S. Gregory (2004). Parent academic involvement as related to School Behaviour, Achievement and Aspirations: Demographic Variations Across Adolescence, Child Development, 75(5): 1491-1509.

17. Jagannadhan, K. (1985). Impact of socio-economic status (rural) on Academic Achievement. Journal of Educational and psychological Researches, 43(2), 129-134.

18. Jagannadhan, K. (1986). Impact of socio-economic status (urban) on Academic Achievement. Journal of Education and psychology, 44(2\&3), 128-134.

19. Kang,T.K. and Sibia, R. (1997). A comparative study of parent-child relationships of high and

20. low achievers. Indian Psychological Review, 48(2),105 - 107.

21. Kannappan, R. (1989). Academic performance, Inter personal behavior and attitudes of children of alcoholic and non alcoholic families. Asian Journal of psychological and Education, 22(7-8), 7-12.

22. Khare, S. (1996). Home learning environment and Academic Achievement of elementary school children. Indian Psychological Review, 46(3-4), 5-61.

23. Ladd, G.W. \& Joseph, M.P.(1986). Promoting children's cognitive and social competence: The relation between parents' perception of task difficulty and children's perceived and actual competence. Child Development, 5, 446-466.

24. Lohani, I. \&Mohite, P. (1990). Link between selected family demographic factors, home environment and academic performance. Perspectives in Education, 6(2),119-124.

25. Lakshmi, Raj, Aishwarya and Arora, Meenakshi (2006). Perceived Parental Behaviour as Related to Students' Academic School success and competence". Journal of the Indian Academy of Applied Psychology, 32(1): 47-52.

26. Lan, Chiu-Hui (2005). Relationships among socioeconomic status, parenting, academic achievement, and self-esteem in early and middle adolescence: A longitudinal study. Dissertation Abstract International Section A: Humanities and Social Sciences, 65(12- A): 4519.

27. Meena, Siwach nee Daulta (2008). Impact of home environment on the scholastic achievement of children, J. Hum. Ecol., 23(1): 75-77.

28. Mohanraj, Rani and Latha (2005). Perceived family environment in relation of adjustment and academic achievement. Journal of the Indian Academy of Applied Psychology: 31(1-2): 18-23.

29. Mohanty, B. \& Das, A. (1997). Effects of socio economic status and age on working memory and spelling competence of children. Psycho-lingua, 27(1), 1-9.

30. Muller, Chandra (1993). Parental Involvement and Academic Achievement: An Analysis of Family Resources available to the child. In parents, their children and schools, ed. Barbara Schneider and James S. Coleman, Boulder, Co.: West view.

31. Peng, Samuel, S. and Wright, Deeann (1994). Explanation of Academic Achievement of Asian American Students. The Journal of Educational Research, 87(6): 346-352.

32. Pittman, L.D. and Chase-Lansdale, P.L. (2001). African American adolescent girls in impoverished community parenting style and adolescent outcomes. Journal of Research on Adolescence, 11(2): 199-224.

33. Shearin and Sherin, A. (2002). Parent-adolescent interaction: Influence on the academic achievement of African American adolescent males. Disability and the Black Community, PA 91: 4547.

34. Stevenson, D \& Baker, D. (1987). Family - school relation and the child's school performance. Child Development 58, 1348-1357.

35. Suman,L.N. \& Umapathy, A..(1997). Parent-child relationship and Achievement Motivation. Journal of Psychological Researches,41 (1\&2), 66-73.

36. Suneetha, B. (1997). A study on factors contributing to high Academic Achievement of school 
37. children. Unpublished thesis submitted to ANGRAU.

38. Suneetha, B. \& Mayuri, (1999). Effect of family factors on Academic Achievement of school children. Psycho-lingua,29(1),83-87.

39. Taj,H.(1999). School academic excellence: A product of individual and situational variables. Indian Pschological Review, 52(1), 32-38.

40. Taj,H.(1999). Academic Achievement as a fuction of social class, parent child interaction, dependency behavior \& school management. Psycho-lingua,29(2),153-158.

41. Thakur, Laxmi (2001). Effect of Home Environment on Intelligence and Educational Aspirations. Journal of Education and Psychology, 59(4): 8-15.

42. Thomas, D.L. (2002). Socialization in Context: Connection regulations and autonomy in the family, school and neighbourhood and with peers. Journal of Adolescent Research, 12: 298-315.

43. Vamadevappa, H.V. (2005). Study of the effectiveness of parental involvement on academic achievement among higher primary students. Journal of Educational Research and Extension, 42(2): 23-32.

44. Vijaya lakshmi. (1995).Relationship of Father's economic condition with intelligence and ability of school students. Asian Journal of Psychology and Education, 28(7-8), 1-5. 